\title{
Biodiversity and Conservation of the Evergreen Broad-leaved Forests in Taiwan
}

\author{
Chang-Fu HSIEH, I-Ling LAI, Guo-Zhang SONG Department of Botany, National Taiwan University, \\ Taipei 106, Taiwan \\ Chii-Cheng LIAO Institute of Botany, Academia Sinica, Taipei 115, Taiwan \\ Kuoh-Cheng YANG Department of Biology, Taiwan Forestry Research Institute, Taipei 100, Taiwan
}

\begin{abstract}
In spite of high population density of Taiwan and rapid economic development, the evergreen broad-leaved forests continue to cover about $32 \%$ of the Taiwan Island. The forests occur from sea level to about $2,500 \mathrm{~m}$, and support a diverse flora and a spectrum of four major forest types. The forest flora at all 779 sampling sites contains 569 woody species in 234 genera and 82 families. The most dominant families are Lauraceae, Fagaceae, Theaceae, Rubiaceae, and Euphorbiaceae. They also account for the greatest number of species. The purpose of the present account is to compare and interpret the forest complexes for the four major types of the evergreen broad-leaved forests in Taiwan. The second aim of this paper is to review the forest management and conservation status for the past three centuries.
\end{abstract}

Key Words: Taiwan / broad-leaved forests / zonation / composition / diversity / forest use / management / conservation

The Taiwan Island and its administratively subsidiary islets (Penghu Isles, Hsiaoliouchiouyu, Kueishantao, Lanyu, Lutao, etc.) are geographically around the boundary between the extensive Holarctic and Paleotropical floristic kingdoms. This location, combined with a tall range of mountains, supports a diverse flora of over 4,000 vascular plant species and a spectrum of seven major forest types.

The evergreen broad-leaved forests of Taiwan occur from sea level to about 2,500 $\mathrm{m}$. These forests are usually referred to as the lauro-fagaceous forests (Kudo \& Sasaki, 1931). They show much variation in zonation patterns due to overlapping of the tropical and temperate zonation types (Ohsawa, 1993). Most of the forests in lowlands have been cleared for agriculture and industry and only a few modified remnants are left. However, in relatively undisturbed forests in the mountains, there are many lianas, epiphytes and ferns and a great variety of trees and shrubs. The dominant tree species include evergreen members of Fagaceae, Lauraceae, Theaceae, Symplocaceae and other broad-leaved evergreen species. The flora of Taiwan is relatively well known. The composition and distribution of plant communities are known only incompletely because of the complexity and diversity of the vegetation and the difficulty of access in the mountain regions. The purpose of the present account is to compare and interpret the forest complexes of the evergreen broad-leaved forests in Taiwan. The second aim of this paper is to review the forest management and conservation status for the past three 


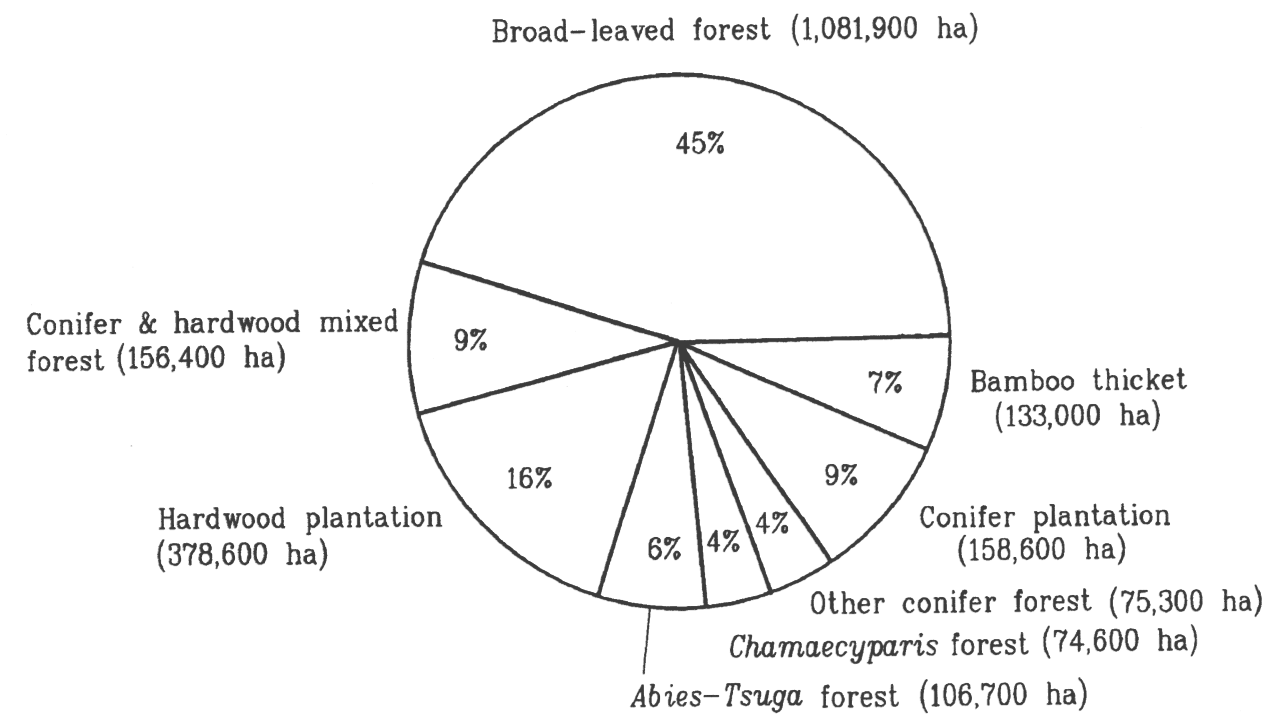

Fig. 1. Forested area in Taiwan. The total area of the forest lands is $1,864,700$ ha, $83 \%$ of which is nation-owned.

centuries.

The data used were derived from published vegetation surveys (Wang, 1975; Su \& Wang, 1988; Hsieh, 1989a, 1989b; Hsieh et al., 1989, 1990a, 1990b; Wang, 1991; Chen, 1993), as well as unpublished theses and reports (Li, 1986; Lin, 1988; Chen, 1990; Chen, 1991; Hsu, 1991; Lu, 1991; Yang, 1991; Chen, H. P. 1992; Chen, Y. S. 1992; Sun, 1993; Chung, 1994; Yang, 1994; Yeh, 1994; Kao, 1995; Liao, 1995; Chen, 1996; Song, 1996; Yeh \& Fan, 1996). In sum, woody species (trees and shrubs) data were collected for 779 forest sites. Then the data for each species was transformed into a single importance value (at an octave scale) for each plot. Gamma diversity were measured using Hill's diversity numbers (Hill, 1973): N0 was the total number of species encountered in the plots, N1 measured the number of abundant species, and N2 was the number of very abundant species. Family importance value (FIV) was calculated as the sum of all species importance values within that family.

\section{PHYSICAL ENVIROMENT}

Taiwan is geographically commonly regarded as a constituent of the island-arc system along the western edge of the Pacific Ocean. Extending $394 \mathrm{~km}$ along its longest axis (ca. $25^{\circ} 20^{\prime} \mathrm{N}$ to $21^{\circ} 55^{\prime} \mathrm{N}$ ) and stretching $140 \mathrm{~km}$ at its broadest transection, this island measures about $35,800 \mathrm{~km}^{2}$. The Tropic of Cancer nearly slices through its middle part.

Taiwan is dominated by forested mountains, with $30 \%$ of its area strongly undulating between 1,000-3,000 m above sea level. Peaks above 3,000 $\mathrm{m}$ in elevation amount to more than 200 in number; all of them are located within the so-called Central Range. This lofty range runs basically following the axis of the island. The lowlands in the central and southern part of western Taiwan occupy about one third of the island. They have been subjected to intensive cultivation, heavy urbanization and industrialization.

Taiwan has a distinct oceanic subtropical climate. Tempered by winds from the sea and by frequent rains and typhoons, the climate is mild and with high humidity throughout the year. 
However, since temperature decreases with increasing elevation, the mountains in Taiwan encompass a climatic range from subtropical to sub-arctic zones. Taiwan is geographically well within the Pacific monsoon zone. Because the N-S trending lofty ranges intersect obliquely the monsoon winds, the southwestern and northeastern parts of the island enjoy different climates. In the winter months the rains are mainly due to the northeast monsoon winds, which bring much rain over the northern, northeastern, and eastern Taiwan, but have little effect on the climate of the southern part. As a result, distinct rainy and dry seasons are present in the southwest. In summer and fall heavy rains fall with typhoons that usually sweep over the whole island.

In spite of its high population density and rapid economic development, about $52 \%$ of Taiwan is still covered by forests (Fig. 1). There has been little human exploitation of the relatively inaccessible high mountain forests (above 2,500 m). By contrast, a great deal of the mixed coniferous forests at middle altitudes, especially those of Chamaecyparis obtusa var. formosana and $C$. formosensis, have been exploited since the very beginning of this century. In low montane regions, logging have converted large expanses of virgin forests to orchards, tea gardens, and plantations of Cryptomeria japonica, Cunninghamia lanceolata, Acacia confusa, Aleurites montana, Cinnamomum camphora, and various bamboos. Forests that remain relatively intact are those growing in the nearly inaccessible areas in eastern Taiwan or those protected in forest reserves and national parks. In lowland areas, nearly all of the natural vegetation was completely destroyed under the impact of intense cultivation, urbanization, and industrialization. Little is known about their original physiognomy or composition.

\section{FOREST TYPES}

Due to steepness of the slopes and the marked correlation between elevation and each of the temperature and moisture, the vertical zonation of the vegetation is especially impressive in the mountainous regions of Taiwan. Striking differences between the vegetation in northern, central, and southern parts at a given elevation may be described as a shifting of the elevation position of the vegetation zones. However, there have been few major attempts to describe broad-scale altitudinal and geographical patterns of Taiwan vegetation. Liu (1968) presented the first comprehensive classification of the island-wide vegetation. Three climax formations of the broad-leaved forests were recognized: warm-temperate montane coniferous forest (1,200-2,200 m), warm-temperate rain forest (700-1,800 $\mathrm{m}$ in north, $900-2,100 \mathrm{~m}$ in south) and tropical rain forest (lower than 700 or $900 \mathrm{~m}$ ). In his study of the relationships between climatic factors and forest vegetation along an altitudinal gradient, Su (1984) recognized seven vegetation zones (Table 1). Among them, four belong to the evergreen broad-leaved forests: Ficus-Machilus zone, Machilus-Castanopsis zone, lower Quercus zone and upper Quercus zone. In the following account of the forests, Su's classification is followed.

Table 1. Temperature ranges of altitudinal vegetation zones in central Taiwan. Tm is annual temperature and WI, the warmth index (Su 1984).

\begin{tabular}{llcccl}
\hline $\begin{array}{l}\text { Altitudinal } \\
\text { zone }\end{array}$ & Vegetation & Altitude $(\mathrm{m})$ & $\mathrm{Tm}^{\circ} \mathrm{C}$ & WI ${ }^{\circ} \mathrm{C}$ & $\begin{array}{l}\text { Equivalent } \\
\text { climate }\end{array}$ \\
\hline $\begin{array}{l}\text { alpine } \\
\text { subalpine }\end{array}$ & alpine vegetation & $>3600$ & $<5$ & $<12$ & subarctic \\
upper montane & Abies & $3100-3600$ & $5-8$ & $12-36$ & cold-temperate \\
montane & Quercus (upper) & $2000-2500$ & $11-14$ & $72-108$ & temperate \\
& Quercus (lower) & $1500-2000$ & $14-17$ & $108-144$ & warm-temperate \\
submontane & Machilus-Castanopsis & $500-1500$ & $17-23$ & $144-216$ & subtropical \\
foothill & Ficus-Machilus & $<500$ & $>23$ & $>216$ & tropical \\
\hline
\end{tabular}




\section{SPECIES COMPOSITION AND DIVERSITY}

\section{Ficus-Machilus forests}

As stated before, large expanses of lowland Taiwan are now agricultural lands, waste grasslands, plantations and secondary forests. The original vegetation there has been at best reduced to vulnerable remnants. In hilly regions, the primary forests or old-growth of secondary forests are confined to the most rugged slopes or officially or privately protected area. Many species of Ficus and Machilus are, however, common in all these forests.

A total of 282 woody species were found in the 148 lowland plots (Table 2). They belong to 63 families and 162 genera. All measures of gamma diversity are relatively lower than those of the Machilus-Castanopsis forest zone due to human exploitation. The most important families in terms of number of species are Euphorbiaceae (28 species), Lauraceae (27), Moraceae (19), Rubiaceae (18), Leguminosae (12), Rutaceae (11) and Fagaceae (10). A total of 15 families have family important values over 2. Eight of the top families are Euphorbiaceae (FIV=12.7), Moraceae (9.5), Lauraceae (8.8), Rubiaceae (6.0), Meliaceae (5.6), Rutaceae (4.8), Lythraceae (3.7) and Urticaceae (3.4). The most abundant species, as indicated by IV, are Lagerstroemia subcostata, Bischofia javanica, Dysoxylum kuskusense, Laportea pterostigma, Machilus japonica var. kusanoi, Schefflera octophylla, Ardisia sieboldii, Diospyros eriantha, Champereia manillana, Ficus fistulosa, Turpinia ternata, Sapindus mukorossii, Sloanea formosana, Ficus irisana, Scolopia oldhamii, Gordonia axillaris, Acacia confusa, Ficus benjamina, Aglaia elliptifolia, Ficus septica, Drypetes hieranensis, Cinnamomum reticulatum, and Gardenia jasminoides in the tree stratum, and Psychotria rubra, Glycosmis citrifolia and Murraya paniculata in the shrub stratum.

The most diverse and least disturbed lowland evergreen broad-leaved forests are found in Nanjenshan Preserve of Kenting National Park in southernmost Taiwan (Liao, 1995). They are composed of a great number of species of trees, shrubs, climbers, lianas, and epiphytes, with a continuous canopy exceeding $20 \mathrm{~m}$ in height in least windy habitats (below $300 \mathrm{~m}$ a.s.l.). Dominant species are Dysoxylum hongkongense, Aglaia elliptifolia, Bischofia javanica, Ficus benjamina, $F$. ampelas, F. variegata var. garciae, Laportea pterostigma, Sloanea formosana, Castanopsis indica and Melicope semecarpifolia.

Many of the species native to Lanyu and Lutao, two of the largest outlying islands of Taiwan, are also present in the Taiwan Island, whereas those absent in Taiwan clearly show an affinity with Philippine flora. The most common trees in the forests there are Cinnamomum tenuifolium $f$. nervosum, Myristica cagayanensis, Flacourtia rukam, Elaeocarpus argenteus, Eurya acuminata, Dehaasia incrassata, Endiandra coriacea, Litsea garciae, Neolitsea sericea var. aurata, N. villosa, Artocarpus incisus, Ficus heteropleura, F. cumingii var. terminalifolia, Cypholophus moluccanus,

Table 2. Gamma diversity of the evergreen broad-leaved forests in Taiwan. Fam is the number of families; Gen is the number of genera; N0 is the number of all species; N1 measures the number of abundant species; $\mathrm{N} 2$ is the number of very abundant species; $\mathrm{S}$ is Simpson index; and $\mathrm{H}$ is Shannon index.

\begin{tabular}{llllllrl}
\hline Forest type & Fam & Gen & N0 & S & H & N1 & N2 \\
\hline Ficus-Machilus & 63 & 161 & 282 & 0.965 & 4.23 & 69 & 28 \\
Machilus-Castanopsis & 72 & 195 & 413 & 0.989 & 5.06 & 158 & 95 \\
Lower Quercus & 66 & 157 & 384 & 0.984 & 4.71 & 111 & 62 \\
Upper Quercus & 51 & 117 & 241 & 0.952 & 3.72 & 41 & 21 \\
Broad-leaved forest & 82 & 234 & 569 & 0.990 & 5.18 & 177 & 99 \\
\hline
\end{tabular}


Villebrunea trinervis, Leucosyke quadrinervia, Laportea batanensis, Syzygium simile, S. densinervium var. insularis, Turpinia ovalifolia, Aglaia elliptifolia, Pometia pinnata, Diospyros discolor, Bischofia javanica, Pouteria duclitan, Podocarpus macrophyllus, Buxus liukiuensis, and Semecarpus cuneiformis (Liu \& Lin, 1978).

\section{Machilus-Castanopsis forests}

The Machilus-Castanopsis forests are prevalent in the lower montane areas, usually occurring at 500$1,500 \mathrm{~m}$ elevation in central Taiwan, but at 300-800 $\mathrm{m}$ in the north and south. In the upper montane areas (800-2,000 $\mathrm{m}$ in the north and 1,500-2,500 $\mathrm{m}$ in the central), the Machilus-Castanopsis forests grade into evergreen oak forests. Forests of this type are usually susceptible to frequent human disturbance. Relatively intact or unaltered forests are largely restricted to the eastern part of the Island. Floristically and physiognomically, the forests are greatly modified by topographic position, aspect, position relative to moisture gradients, and disturbances.

The vascular flora of the 238 sampling plots is composed of 413 species in 195 genera and 72 families (Table 2). The most important families in terms of number of species are Lauraceae (43 species), Fagaceae (25), and Moraceae (25), followed by Rubiaceae (24), Euphorbiaceae (22), Theaceae (20), Rosaceae (17), Aquifoliaceae (16), Rutaceae (15), Symplocaceae (14), Araliaceae (11), Leguminosae (11), Myrsinaceae (11), Verbenaceae (11), and Saxifragaceae (10). A total of 12 families have family IV over 2. Eight of the top families are Lauraceae (FIV=17.7), Fagaceae (8.6), Rubiaceae (6.1), Euphorbiaceae (5.3), Myrsinaceae (5.2), Theaceae (4.8), Araliaceae (4.6), and Moraceae (4.2). The principal tree species in order are Schefflera octophylla, Machilus thunbergii, Ardisia sieboldii, Turpinia formosana, Beilschmiedia erythrophloia, Lagerstroemia subcostata, Machilus japonica var. kusanoi, Daphniphyllum glaucescens ssp. oldhamii, Villebrunea pedunculata, Litsea acuminata, Helicia formosana, Engelhardtia roxburghiana, Mallotus paniculata, Cyclobalanopsis glauca, Elaeocarpus sylvestris and Wendlandia formosana. The most dominant shrub species include Psychotria rubra, Glycosmis citrifolia, Hydrangea chinensis, Ardisia cornudentata, Arenga engleri, Vibrunum odoratissimum and Maesa tenera.

\section{Lower Quercus forests}

The lower Quercus forests usually form a continuous tract along the western fringe of the Central Range and the eastern fringe of the Eastern Taiwan Schist Range. A large number of tree species appear in these montane evergreen broad-leaved forests. The lower and upper Quercus forests experience heavy cloud cover and frequent fog. Their canopy may reach about $30 \mathrm{~m}$ tall. Here bryophytes develop luxuriantly; they may swathe tree boles and crowns in great festoons along with lichens. The stratification is characteristically three or four layers.

A total of 384 woody species, representing 157 genera and 66 families, are recorded in the 277 plots (Table 2). All indices of gamma diversity are lower than those of the Machilus-Castanopsis forests. The largest two families are Lauraceae (43 species) and Fagaceae (27), followed by Theaceae (23), Rubiaceae (21), Aquifoliaceae (20), Rosaceae (20), Ericaceae (17), Symplocaceae (15), Moraceae (14) and Euphorbiaceae (13). The most importance families in terms of species abundance are Lauraceae (FIV=16.6), Fagaceae (13.7), Theaceae (9.5), Myrsinaceae (6.2), Rubiaceae (5.2), Elaeocarpaceae (3.9), Aquifoliaceae (3.6), Symplocaceae (3.5), Rosaceae (2.8), Araliaceae (2.8), Juglandaceae (2.6), Saxifragaceae (2.5) and Ericaceae (2.4). The major canopy or subcanopy tree species in order of importance are Machilus thunbergii, Myrsine seguinii, Cyclobalanopsis longinux, Litsea acuminata, Engelhardtia roxburghiana, Elaeocarpus japonicus, Diospyros morrisiana, 
Castanopsis carlesii, Syzygium buxifolium, Daphniphyllum glaucescens ssp. oldhamii, Illicium arborescens, Schefflera octophylla, Adinandra formosana, Eurya japonica, Ardisia sieboldii, Prunus phaeosticta, and Cyclobalanopsis acuta var. paucidentata. Eurya acuminata usually dominates the shrub stratum. The secondary shrubs are Psychotria rubra, Antidesma japonicum var. densiflorum, Lasianthus fordii, Hydrangea angustipetala, Blastus cochinchinensis, Ardisia cornudentata and Hydrangea chinensis.

\section{Upper Quercus forests}

Between 1,900 (1,500 in the north) and 2,500 m, the broad-leaved forests usually give way to some conifers, and thus form a zone of mixed montane forests. It has been assumed that these forests represent a penultimate stage in a succession from coniferous pioneer stages toward a climax of exclusively broad-leaved trees, the upper Quercus forests. Logging of the highly-prized Chamaecyparis formosensis during 1900-1980 has greatly reduced the area of the virgin stands of this type. These forests consist primarily of evergreen broad-leaved trees with conspicuous emergent conifers including Chamaecyparis formosensis, C. obtusa var. formosana, Taiwania cryptomerioides, Pinus armandii var. masteriana, P. taiwanensis and Picea morrisonicola. These conifers often grow to a height of $40-50 \mathrm{~m}$, with the stems $100-200 \mathrm{~cm}$ in dbh.

The upper Quercus forests have the lowest gamma diversity. A total of 241 species were recorded in the 116 plots, belonging to 117 genera and 51 families (Table 2). Families with more than 10 species include Lauraceae (24 species), Fagaceae (20), Rosaceae (18), Ericaceae (17), Theaceae (17), Aquifoliaceae (14) and Symplocaceae (13). The most importance families in terms of species abundance are Lauraceae (FIV=16.1), Theaceae (14.2), Fagaceae (14.1), Ericaceae (5.8), Araliaceae (4.5), Symplocaceae (4.3), Rosaceae (3.2), Aquifoliaceae (3.0) and Caprifoliaceae (2.6).These forests share many species with the lower evergreen oak forest. However, the composition of the subcanopy species gradually changes with the altitude. Trees becoming dominant include Castanopsis carlesii, Neolitsea acuminatissima, Rhododendron ellipticum, Cleyera japonica, Chamaecyparis formosensis, Dendropanax pellcidopunctata, Trochodendron aralioides, Cinnamomum randaiense, Schima superba, Ternstroemia gymnanthera, Acer morrisonense, and Lithocarpus lepidocarpus. The dominant shrubs are Eurya acuminata, Barthea formosana, Eurya leptophylla, Pittosporum illicioides, Viburnum taiwanianum, Vaccinium bracteatum, Viburnum integrifolium and Skimmia reevesiana.

\section{FOREST USE, MANAGEMENT AND CONSERVATION STATUS}

In early stage when Han people moved to Taiwan, the timber used for construction was mainly imported from Mainland China. Due to the aborigines had expelled and resisted the outsiders, it was difficult for Han people to develop the hillside of the Taiwan area. In the year 1886, although the Ching Dynasty set up the Timber Bureau in Taiwan, the volume of timber cutting should be limited, and the timber obtained should be mostly from the lowland broad- leaved forests.

During the earlier period of Japanese occupation of Taiwan, the forest lands covered approximately 2.47 million hectares (Liu, 1992). The total population at that time was only around 3 million. Forest resources, one of the richest natural resources in Taiwan, were never exhausted if an appropriate management could be carried out. To seek a sustainable use of the forest resources, the Governor-General strove to manage them carefully. Accordingly, the forest lands were divided into several areas by different purposes, such as 2 million hectares of nation-owned forest land, 143,010 
hectares of wild forest land for public, private, agricultural uses, and 205,000 hectares of protected mountain land for aborigines to live.

In addition, the Governor-General also actively developed natural forest resources in Taiwan. Camphor, the most valuable product from lower montane camphor trees, was produced and exported in great quantities. Thus, the government looked upon camphor as a special product, and the management had been put under the Taiwan Governor Office's Monopoly Bureau. Apart from camphor trees and a few special species, such as Zelkova, Michelia, etc., the other broad-leaved trees had only limited ways of utilization. During that period, the wood used commercially in Taiwan was mainly coniferous timber. The domestic consumption of lumber was much higher than the production in Taiwan. Therefore, the lumber shortage was made up by importing some cheaper conifers from Japan, China and America. However, a certain quantity of high-grade Taiwan cypress was exported to Japan.

Since 1937 the import market of lumber in Taiwan was deeply affected by the war. The import of coniferous timber was cut off finally. Owing to the ever-increasing demand for lumber, the government had to take emergent actions to expedite domestic production of lumber to fulfill the demand, such as to exploit the broad-leaved forests, to encourage private sectors to log and harvest the forests in nation-owned forest land, wild fields and protected mountain forests. The effect of implementing these actions had not only created a new way to utilize the broad-leaved forests, but also made the people acclimated to use the lumber of broad-leaved trees (Shen, 1974).

In the meantime, the governor selected three areas (Hsiankao/Alishan, Tsekao/Taroko, and Tatun) as preliminary sites for national parks. The total area was 460,000 hectares. Although the plans were halted due to the Pacific War, the regulations, system and scope of national park-related matters already existed in embryonic form.

During the Pacific War time, the demand of lumber for defense and national uses increased enormously. It once caused over-exploitation of the forests, and even destroyed the planned management programs.

After World War II, the management practices were mainly designed to restore timber production, and meanwhile to rehabilitate destroyed forest areas. In the $1960 \mathrm{~s}$, the increasing development of domestic industries and businesses and the expanded trade market in Taiwan, had brought all sorts of timber industries to thrive. The lumber market reached a most prosperous stage than before. At this time, the industries for wood fiber, pulp, plywood, wooden wares, furniture caused an extensive clearing of the broad-leaved forests in the lower montane areas. Moreover, parts of the forests were destroyed by various scales of timber stand improvement in areas of low and middle altitudes.

In 1975 the Executive Yuan announced three guide principles of forestry policy. Under the principles, the Forestry Bureau worked out a "Taiwan Forest Management and Renovation Program". Taiwan's forestry policy then entered into another new era, with goals to decrease timber production, and to strengthen forest functions such as soil conservation, recreation, public education, etc. In the following years, the government enacted several important laws, such as Regulations for Hillside Conservation and Utilization in 1976, Cultural Heritage Preservation Law in 1982, Implementation Regulations for National Park Law in 1982, Nature Conservation Project of the Taiwan Area in 1984, Wildlife Conservation Law in 1989, Administrative Regulations for Forest Lands within National Parks or Specific Landscape District in 1990, Conservation Measures for Ecological Reserves and Nature Preserves in 1990, and Taiwan Forestry Management and Administration Acts in 1991.

Under these laws and regulations, five of the most magnificent natural areas of Taiwan have been established as national parks. Besides, thirty-five or more preserves and reserves have been 
established. They altogether occupy nearly $12 \%$ of the total land area of Taiwan, and the broad-leaved forest lands cover most of them. Other than designating areas for habitat protection, an overall policy of forest resource conservation was implemented. This included: the management and protection of forests; the prevention of forest fire; the prevention of unauthorized activities within national forests; timber harvesting limits of 200,000 cubic meters per year, and a six-year moratorium on harvesting of any natural forests. Meanwhile, the Taiwan Forestry Bureau was transformed into an official unit, with all its expenses included in the government budget. This reformation will totally change the existing way of self-supporting production and management.

In spite of its high population pressure and rapid economic development, the evergreen broadleaved forests continue to cover 32\% (1.24 million hectares) of the island. Taiwan's commitment to long-term preservation of the forests is actually less than 15 years old. This effort will, however, make the evergreen broad-leaved forests continuously to be attractive landscape features and an important natural heritage of Taiwan.

\section{CONCLUSION}

Taiwan is a small island with a broad range of environments. It supports a spectrum of seven forest types. Among them, the evergreen broad-leaved forests have a widest species diversity, and are very structurally complex. With a growing demand for economy for the past five decades, almost all lowlands on the island, and an increasing amount of hillsides, are intensively cultivated. However, the Central Mountain Range is the one area still contains the largest amount of the evergreen broad-leaved forests remaining on the island. The protection of these forests is a unique and difficult challenge. Because of the limited scientific resources available of these forests in Taiwan, our knowledge of these forests is remarkably scanty. The rational management of the forests will depend on an adequate knowledge of ecological and silvical characteristics of the trees. An understanding of the functioning of the forest ecosystem as well as of the habitat protection afforded by these forests is also essential. Moreover, the establishment of preserves and reserves are especially important in that they provide security for the unique biodiversity they contain. Taiwan is now striving to balance economic development and environmental protection. The continued presence of the evergreen broad- leaved forests will depend on the enforcement of environmental laws, the protection of key natural areas, and in the long term public recognition of the benefits they provide.

\section{REFERENCES}

Chen C. H. 1996. Vegetation Analysis on the Machilus-Castanopsis Zone of Northwestern Taiwan. Master thesis, Department of Forestry, National Taiwan University, $92 \mathrm{pp}$.

Chen I. M. 1991. Study on the Vegetation Ecology of Taiwan under the Influence of the NE Monsoon Climate. Master thesis, Department of Forestry, National Taiwan University, $94 \mathrm{pp}$.

Chen H. P. 1992. Vegetation Analysis and Tree Distribution in Wuchihshan Area, Northeastern Taiwan. Master thesis, Department of Forestry, National Taiwan University, 78 pp.

Chen M. S. 1990. Vegetation Analysis on the Lower Laonungchi Valley, Southern Taiwan. Master thesis, Department of Forestry, National Taiwan University, $82 \mathrm{pp}$.

Chen T. I. 1993. Vegetation analysis on the broad-leaved forests of Machilus-Castanopsis forest zone in northern Taiwan. Q.J. Exp. For. Natl. Taiwan Univ. 7 (3): 127-146.

Chen Y. S. 1992. Vegetation of the Upper Tonachi Watershed. Master thesis, Department of Forestry, 
National Taiwan University, $100 \mathrm{pp}$.

Chung N. J. 1994. Study on the Vegetation Ecology of the Salisen Watershed. Dissertation, Department of Forestry, National Taiwan University, $183 \mathrm{pp}$.

Hill, M. O. 1973. Diversity and evenness: A unifying notation and its consequences. Ecology 54: 427249.

Hsieh, C. F. 1989a. Structure and floristic composition of the beech forest in Taiwan. Taiwania 34: 2844.

Hsieh C. F. 1989b. Structure and floristic composition of the warm-temperate rain forest of the Kaoling Area. J. Taiwan Mus. 42 (2): 31-41.

Hsieh C. F., Hsieh T. H. \& Lin S. M. 1989. Structure and succession of the warm-temperate rain forest at Techi Reservoir. J. Taiwan Mus. 42 (2): 77-89.

Hsieh C. F., Huang T. C., Yang K. C. \& Huang S. F. 1990a. Vegetation patterns and structure of secondary forest on Mt. Lonlon, northeastern Taiwan. Taiwania 35: 207-220.

Hsieh C. F., Huang T. C., Hsieh T. F., Yang K. C. \& Huang S-F. 1990b. Structure and composition of the windward and leeward forests in the Wushipi Nature Preserve, northern Taiwan. J. Taiwan Mus. 43 (2): 157-166.

Hsu Y. M. 1991. Structure and Composition of the Warm-temperate Rain Forest of Lopei Mountain, Northern Taiwan. Master thesis, Department of Botany, National Taiwan University, 82 pp.

Kao Y. C. 1995. Vegetation Analysis on the Forest of the Liwuchi Watershed, Eastern Taiwan. Master thesis, Department of Forestry, National Taiwan University, $121 \mathrm{pp}$.

Kudo, Y. \& Sasaki, S. 1931. An ecological survey of the vegetation of the border of Lake Jitsugetsutan. Ann. Rep. Taihoku Bot. Gard. 1: 1-50.

Li M. Z. 1986. Vegetation Survey of the Forest in Shihting-Pingchi Area, Northeastern Taiwan. Master thesis, Department of Forestry, National Taiwan University, 53 pp.

Liao C. C. 1995. Altitudinal Pattern in Species Composition, Diversity and Structure of a Subtropical Rain Forest in Nanjenshan, Southern Taiwan. Master thesis, Department of Botany, National Taiwan University, $82 \mathrm{pp}$.

Lin S. H. 1988. Studies on the Vegetation Ecology of the Nanao Hardwood Reserve. Master thesis, Department of Forestry, National Taiwan University, 118 pp.

Liu N. Y. 1992. General History of Taiwan Province: Forestry. Taiwan Province Document Committee, 1034 pp.

Liu T. 1968. Studies on the classification of the climax vegetation communities of Taiwan, I: Classification of the climax formations of the vegetation of Taiwan. Bull. Taiwan For. Res. Inst. No. 166,25 pp.

Liu T. S. \& Lin T. T. 1978. Studies on the vegetation and flora of Lanyu. Ann. Taiwan Mus. 21: 1-80.

Lu E. C. 1991. Vegetation Analysis on the Mixed Conifer-broadleafforest of the Peitawushan Reserve. Master thesis, Department of Forestry, National Taiwan University, 108 pp.

Ohsawa, M. 1993. Latitudinal pattern of mountain vegetation zonation in southern and eastern Asia. $J$. Veg. Sci. 4: 13-18.

Shen S. C. 1974. On the timber production and market of Taiwan. Taiwan Forestry 1 (1): $41-43$.

Song G. Z. 1996. Species Composition and Distribution Patterns of the Temperate Evergreen Broadleaved Forest of Mt. Peitungyen, Central Taiwan. Master thesis, Department of Botany, National Taiwan University, $72 \mathrm{pp}$.

Su H. J. \& Wang L. C. 1988. Vegetation types in the upper watershed of the Nanshihchi, northern Taiwan. Q. J. Exp. For. Natl. Taiwan Univ. 2 (4): 89-100. 
Su H. J. 1984. Studies on the climate and vegetation types of the natural forest in Taiwan. (II). Altitudinal vegetation zones in relation to temperature gradient. Q.J. Chin. For. 17 (4): 57- 73.

Sun I. F. 1993. The Species Composition and Forest Structure of a Subtropical Rain Forest at Southern Taiwan. Thesis, Univ. Calif. Berkeley, 205 pp.

Wang C. K. 1975. Ecological study of the tropical strand forest of Hengchun Peninsula. Biol. Bull. Tunghai Univ. 16: 1-28.

Wang S. H. 1991. Ordination and classification of vegetation in Sanping and Nanfenshan Area. Q.J. Taiwan For. Res. Inst. 6 (2): 185-201.

Yang J. J. 1994. Woody Floristic Composition, Structure and Distribution Pattern of the Tropical Seasonal Forest in Nanjenshan Area. Master thesis, Department of Botany, National Taiwan University, $63 \mathrm{pp}$.

Yang S. Z. 1991. Studies on the Hardwood Forest in Chingshuiying Reserve. Taiwan Forestry Bureau, Report No. 80-02, 94 pp.

Yeh C. L. 1994. Synecological Studies on the Montane Vegetation of the Hengchun Peninsula. Dissertation, Department of Forestry, National Taiwan University, 172 pp.

Yeh C. L. \& Fan K. C. 1996. Study on the Vegetation Ecology of Taitung Macaca cyclopsis Nature Reserve. Taiwan Forestry Bureau, Report No. 84-01-3, 76 pp.

HSIEH, C.-F. , LAI, I-Ling, SONG, Guo-Zhang, LIAO, Chii-Cheng, YANG, KuohCheng 台湾における照葉樹林の生物多様性と保護

台湾における高い人口密度と急速な経済発展にもかかわらず, 常緑広葉樹林は引き続き台湾島の面積 の32\%を占めている。この森林は海岸域から海抜 $2500 \mathrm{~m}$ に分布し, 多様な植物相と 4 つの主要森林 型を支えている。779 の調査区での森林の植物相は木本植物 570 種を含み, 234 属, 82 科に及んでい る。最も種の数が多い科はクスノキ科, ブナ科, ツバキ科, アカネ科, トウダイグサ科であった。本 研究の第 1 の目的は, 台湾における常緑広葉樹林の 4 主要型について比較解釈をすることである。第 2 の目的は過去 3 世紀に亘るこれらの森林の管理と保護の状況を概括することである。 